\title{
Mechanical and Electrical Ageing Effects on the Long-Term Stretching of Silicone Dielectric Elastomers with Soft Fillers
}

Long-Term Stretching of Silicone Dielectric Elastomers

Madsen, Frederikke Bahrt; Zakaria, Shamsul Bin; Yu, Liyun; Skov, Anne Ladegaard

Published in:

Advanced Engineering Materials

Link to article, DOI:

10.1002/adem.201600074

Publication date:

2016

Document Version

Peer reviewed version

Link back to DTU Orbit

Citation (APA):

Madsen, F. B., Zakaria, S. B., Yu, L., \& Skov, A. L. (2016). Mechanical and Electrical Ageing Effects on the Long-Term Stretching of Silicone Dielectric Elastomers with Soft Fillers: Long-Term Stretching of Silicone Dielectric Elastomers. Advanced Engineering Materials, 18(7). https://doi.org/10.1002/adem.201600074

\section{General rights}

Copyright and moral rights for the publications made accessible in the public portal are retained by the authors and/or other copyright owners and it is a condition of accessing publications that users recognise and abide by the legal requirements associated with these rights.

- Users may download and print one copy of any publication from the public portal for the purpose of private study or research.

- You may not further distribute the material or use it for any profit-making activity or commercial gain

- You may freely distribute the URL identifying the publication in the public portal 


\title{
Mechanical and electrical ageing effects on the long-term stretching of silicone dielectric elastomers with soft fillers
}

\author{
Frederikke B. Madsen ${ }^{a}$, Shamsul Zakaria ${ }^{a, b}$, Liyun Yu ${ }^{a}$ and Anne L. Skov ${ }^{a *}$
}

aDanish Polymer Centre, Department of Chemical and Biochemical Engineering, Technical University of Denmark, DTU, Søltofts Plads, Building 227, 2800 Kgs. Lyngby, Denmark

${ }^{b}$ Faculty of Industrial Science and Technology, Universiti Malaysia Pahang, Lebuhraya Tun Razak 26300

Gambang, Pahang, Malaysia.

*E-mail: al@kt.dtu.dk

\begin{abstract}
Dielectric elastomer materials for actuators need to be soft and stretchable while possessing high dielectric permittivity. Soft silicone elastomers can be obtained through the use of silicone oils, while enhanced permittivity can be obtained through the use of dipolar groups on the polymer backbone. Such elastomers were prepared by adding soft fillers to a strong and relatively stiff elastomer, Elastosil LR3043/50. The long-term stability of the materials was tested by straining the elastomers $60 \%$ statically for up to three months. The results showed that soft fillers significantly influence the long-term stability of silicone elastomers, with electrical breakdown strength being the most influenced. Especially high concentrations of silicone oils should be avoided for long-term mechanical stability.
\end{abstract}

\section{Introduction}

Dielectric elastomers (DEs), which consist of thin elastomer films sandwiched between compliant electrodes, constitute a promising area of soft transducers. ${ }^{[1][2]}$ What sets DEs apart from other transducer technologies is their flexibility and ability to produce high extensions. For the full implementation of DEs into commercial products, however, a significant leap in material technology is still required. In particular, the lifetime of elastomer materials 
needs further investigation, understanding and optimisation, and there is also a great need for a holistic view on elastomer properties - as discussed in a current review on dielectric elastomer materials. ${ }^{[3]}$

Moreover, more focus should be put on the fact that different applications require materials with different properties. For sensors, for instance, many different elastomers can be used without a problem, which is why sensors have found more widespread commercial use up to this point. Conversely, for actuators, soft and very extensible elastomers are needed, whereas for generators stiffer and more durable elastomers are required. Therefore, attention should focus on elastomer material. In particular, improving the properties of elastomers could lead to better DE performance by, for instance, reducing driving voltage, which is now typically in the lower $\mathrm{kV}$ range. In literature, this has been achieved through increases in the elastomer's dielectric permittivity $\left(\varepsilon^{\prime}\right)$, since the Maxwell stress is proportional to permittivity. Furthermore, elastomers with high dielectric breakdown strength $\left(E_{\mathrm{B}}\right)$ are required, so that the DE does not fail prematurely. Increasing the electrical breakdown strength of DEs has proven a difficult challenge and is usually only achieved through an increase in the Young's modulus $(Y) .{ }^{[4]}$ This, however, significantly decreases obtainable actuation strain and might therefore only be an option for DE generators. In Table 1 the material gaols for ideal DE performance, for the three main DE application types, are shown. The desired properties, however, also depends on the DE device configurations (i.e. stacking, multi-layers, thin films, rolls etc.) The figure of merit, $F_{\text {om }}$, is a universal expression which can be used to compare and evaluate different DE materials (at a constant potential). ${ }^{[5]}$ In Table 1, figures of merit for the requirements have been calculated relative to a commercial benchmark silicone elastomer, namely Elastosil RT625, the properties of which are regarded as follows: $\varepsilon^{\prime}=3, Y=1 \mathrm{MPa}$ and $E_{\mathrm{B}}=80 \mathrm{~V} / \mu \mathrm{m} .{ }^{[6]}$ Additionally - not explicit from the figure of merit - elastomers should possess maximum elongations above $200 \%$ in order to be processable and survive large degrees of straining. More details on other requirements can be found in the recent review by Madsen et al. ${ }^{[3]}$

Table 1. Goals for realising the potential of dielectric elastomers based on the different application types. $F_{o m} *$ gives a measure of required improvement factor. 


\begin{tabular}{|c|c|c|c|c|}
\hline $\begin{array}{l}\text { Type of } \\
\text { transducer }\end{array}$ & {$[\mathrm{MPa}]$} & $\varepsilon^{\prime}$ & {$[\mathrm{V} / \mu \mathrm{m}]$} & $\begin{array}{l}F_{\text {om }}{ }^{*}=\left(\varepsilon^{\prime} / Y^{*} E_{\mathrm{B}}{ }^{2}\right)_{\text {norm }} \\
\text { with respect to } \\
\text { Elastosil RT } 625\end{array}$ \\
\hline Sensor & $\sim 1$ & 3 & $\sim 50$ & 1 \\
\hline Actuator & $<1$ & 10 & 100 & 13 \\
\hline Generator & $\sim 2(1-10 \mathrm{MPa})$ & 10 & 100 & 7 \\
\hline
\end{tabular}

It can be seen from Table 1 that elastomer material requirements for sensors are easily achieved through the use of commercial silicone elastomers, such as Elastosil RT625, as well as most other commercially available silicone elastomers. On the other hand commercial elastomers do not meet material specifications for actuators and generators. Therefore, there is a need for specifically designed elastomers, in order to meet the requirements of these two types of applications. Designing such elastomers, however, is not an easy task. The combination of a high dielectric permittivity of $\varepsilon^{\prime}=10$ (lower (6-8) may also be acceptable) and a high electrical breakdown strength of $E_{\mathrm{B}}=100 \mathrm{~V} / \mu \mathrm{m}$ have proven a difficult challenge, since increases in permittivity have often led to decreases in electrical breakdown strength. ${ }^{[3]}$ A electrical breakdown strength of $80 \mathrm{~V} / \mu \mathrm{m}$, however, may be acceptable for many applications. ${ }^{[3]}$ Furthermore, in order to be commercially viable, DEs should be able to actuate a minimum of 10 million cycles and thereby have a long lifetime. This means that reliable products based on DEs, and thereby also the DE, need to be stable over a long period of time. The commonly used VHB elastomer, for example, is only able to survive a few months of actuation since it is prone to detrimental crack propagation. Additionally, for reliability the DE must be able to maintain important properties over time so that products will not have to be calibrated frequently due to changes, for example, in the Young's modulus - and thus variations in actuation at a given voltage.

Several strategies have been pursued in order to create new elastomers for DE actuators and generators. Soft and high dielectric permittivity DE actuator materials, for example, were prepared through the chemical modification of elastomer by Kussmaul et al. ${ }^{[7]}$, who added the synthesised dipolar molecule $N$-allyl- $N$-methyl- $p$-nitroaniline, together with compensating amounts of a hydride-functional cross-linker, to a silicone matrix. Soft silicone 
elastomers with high permittivity were also prepared by Madsen et al. who used synthesised nitrobenzene- and azonitrobenzene-functional cross-linkers ${ }^{[8]}$ and copolymers ${ }^{[9]}$ while Bele et al. ${ }^{[10]}$ used commercially available functional cross-linkers for condensation cure silicones. Soft elastomers have also been prepared by making advanced network structures, such as through the use of random or heterogeneous bimodal networks ${ }^{[11]}$ or through the preparation of interpenetrating polymer networks (IPNs) $)^{[12]-[16]}$. Also, very recently, Goff et al. ${ }^{[17]}$ presented work on a hetero-bifunctional chain extender which, when condensed, led to infinitely long silicone chains. This ultimately created a material with superior elasticity and without the waxy consistency of traditional highmolecular weight silicones. Finally, softened DEs have been prepared through the use of permittivity-enhancing blends, where polymers such as poly(3-hexylthiophene $)^{[18]}$, polyethylene glycol ${ }^{[19]}$, a cyanopropyl-functional copolymer $^{[20]}$ and chloropropyl-functional silicone oil ${ }^{[21]}$ have been used.

Silicone materials for DE generators may in general be stiffer and less extensible, and so elastomers with rigid permittivity-enhancing fillers such as $\mathrm{TiO}_{2}$ can be excellent candidates ${ }^{[22][23]}$. Composite materials with high stiffness and moderately high permittivity furthermore include elastomers with expanded graphite ${ }^{[24]}$ and encapsulated polyaniline particles. ${ }^{[25]}$ Other materials that have proven ideal for generator applications include interpenetrating ionic networks that have shown predicted high performance at low frequencies. ${ }^{[16]}$

For both actuators and generators a full characterisation of elastomer material is required. Several studies have focused on the dielectric breakdown performance of DEs in relation to the Young's modulus, ${ }^{[4]}$ applied prestrain $^{[26]-[29]}$ and elastomer thickness. ${ }^{[27][29]}$ Electrical breakdown strength can be analysed statistically through a Weibull distribution analysis, from which the probability of electrical breakdown can be determined. The Weibull cumulative distribution function $\left(F\left(E_{\mathrm{B}}\right)\right)$ is:

$F\left(E_{B}\right)=1-\exp \left(-\frac{E_{B}}{\eta}\right)^{\beta}$

where $E_{\mathrm{B}}$ is the measured dielectric breakdown strength, $\beta$ is the Weibull shape parameter and $\eta$ is the Weibull scale parameter. 
Another DE failure mode is electromechanical instability (EMI), or pull-in instability, which might be the most prevalent failure mode for soft dielectrics such as elastomers. ${ }^{[30]}$ The stress-strain behaviour of an elastomer greatly influences EMI and elastomer must therefore possess strain-hardening behaviour in order to be able to suppress EMI. ${ }^{[31]}$ Investigation of the stress-strain behaviour of elastomers over time is therefore imperative, since some elastomers (e.g. highly filled elastomers) may change characteristics and become strain-softening over time, due to the Mullins effect. ${ }^{[32]-[34]}$

In a previous study by Zakaria et al. ${ }^{[34]}$, we investigated the electrical breakdown strength and stress-strain behaviour of commercial filled silicones and composites with hard fillers upon strain-induced ageing. Functional silicones have been another common means of increasing dielectric permittivity, and therefore, in this study, we investigate ageing effects after static straining of functional silicone elastomers. The studied elastomers consist of a strong and relatively stiff commercial elastomer, Elastosil LR3043/50, ideal for generator applications, which is filled with either functional silicone oil, regular polydimethylsiloxane (PDMS)-based silicone oil or functional cocross-linkable silicone copolymers, in order to expand the application area of the high dielectric breakdown strength elastomer Elastosil LR3043/50 to actuator applications. These silicone elastomer modifications may lead to dramatically altered properties over time, and we therefore investigate stress-strain behaviour and dielectric breakdown strength after static straining for different timespans, in order to elucidate the effect on failure modes of the soft additives.

\section{Results and discussion}

\subsection{Properties of different elastomer compositions, before the ageing experiments}

The investigated formulations are based on a strong and well-performing ${ }^{[22]}$ silicone elastomer with high electrical breakdown strength, namely LR3043/50 from Wacker Chemie. Due to its strong and relatively stiff nature this 
pristine elastomer is suitable for generator applications. In order to broaden its scope, and also to make it applicable for actuator purposes, it can be softened through a range of different approaches. Since it is also desired to increase dielectric permittivity, functional silicone oils can be used as an alternative to hard fillers such as $\mathrm{TiO}_{2}$, which has previously been shown to introduce ageing effects in silicone elastomers ${ }^{[34]}$. Functional silicone oils will soften elastomer while at the same time increasing permittivity, and thereby actuator performance will be increased significantly through a synergistic effect. ${ }^{[21]}$ Such additives, however, may induce significant ageing effects due to phase separation and/or migration of the free species. As an alternative to oil, similar softening (functional) copolymers can also be added to the commercial LSR elastomer and reacted into the elastomer structure. ${ }^{[35]}$ This may provide a more stable system over time, since the softening comes from the lubrication effect of chloropropyl groups rather than the solvent effect of oil. Thus, samples with different concentrations of plain silicone oil (PDMS-based), functional silicone oil (chloropropyl-functional) or functional copolymers (with either low or high concentrations of chloropropyl groups, denoted as Co-1 and Co-2, respectively) were prepared. The different sample compositions are shown in Table 5, whilst their properties before any ageing experiments are shown in Table 2. These samples represents the 'control' samples. 
Table 2. Initial properties of samples with oils and copolymers.

\begin{tabular}{|c|c|c|c|c|c|c|c|}
\hline No & Composition & $\begin{array}{l}\text { Breakdo } \\
\text { wn } \\
\text { strength } \\
{[\mathrm{V} / \mu \mathrm{m}]} \\
\end{array}$ & $\begin{array}{l}\text { Y @ 5\% } \\
\text { strain } \\
\text { [MPa }]\end{array}$ & $\begin{array}{l}\text { Tensile } \\
\text { strength } \\
\text { [MPa] }\end{array}$ & $\begin{array}{l}\text { Strain } \\
@ \\
\text { break } \\
{[\%]}\end{array}$ & $\varepsilon '$ & $\begin{array}{l}\boldsymbol{F}_{\text {om_ref }} \\
/ \boldsymbol{F}_{\mathrm{om}}\end{array}$ \\
\hline$\# 1$ & LR3043/50 & $181 \pm 6$ & $2.41 \pm 0.09$ & $5.23 \pm 0.36$ & $717 \pm 17$ & 2.7 & 1.0 \\
\hline$\# 2$ & Co-1 pure $+25 \mathrm{wt} \% \mathrm{SiO}_{2}$ & $66 \pm 4$ & $0.15 \pm 0.02$ & $0.65 \pm 0.10$ & $429 \pm 15$ & 4.7 & 4.2 \\
\hline \#3 & $\mathrm{Co}-2$ pure $+25 \mathrm{wt} \% \mathrm{SiO}_{2}$ & $69 \pm 5$ & $0.52 \pm 0.04$ & $1.27 \pm 0.12$ & $314 \pm 10$ & 5.1 & 1.4 \\
\hline$\# 4$ & LR3043/50 + 30 phr Co-1 & $122 \pm 14$ & $1.90 \pm 0.05$ & $6.51 \pm 0.42$ & $596 \pm 18$ & 3.1 & 0.8 \\
\hline$\# 5$ & LR3043/50 + 30 phr Co-2 & $113 \pm 9$ & $2.00 \pm 0.06$ & $5.06 \pm 0.34$ & $314 \pm 12$ & 3.5 & 0.7 \\
\hline \#6 & LR3043/50 + 100 phr Co- 1 & $83 \pm 5$ & $1.09 \pm 0.07$ & $1.06 \pm 0.18$ & $254 \pm 13$ & 3.3 & 0.6 \\
\hline \#7 & LR3043/50 + 100 phr Co- 2 & $89 \pm 7$ & $1.29 \pm 0.05$ & $3.71 \pm 0.21$ & $256 \pm 15$ & 3.6 & 0.7 \\
\hline$\# 8$ & $\begin{array}{l}\text { LR3043/50 + } 30 \text { phr LMS- } \\
152 \text { (chloro-oil) }\end{array}$ & $120 \pm 10$ & $1.73 \pm 0.08$ & $3.34 \pm 0.22$ & $481 \pm 16$ & 4.4 & 1.1 \\
\hline \#9 & $\begin{array}{l}\text { LR3043/50 + } 100 \text { phr LMS- } \\
152 \text { (chloro-oil) }\end{array}$ & $62 \pm 8$ & $0.60 \pm 0.05$ & $0.78 \pm 0.11$ & $269 \pm 12$ & 5.6 & 1.1 \\
\hline$\# 10$ & $\begin{array}{l}\text { LR3043/50 + } 30 \text { phr DMS- } \\
\text { T22 (silicone-oil) }\end{array}$ & $98 \pm 6$ & $0.87 \pm 0.05$ & $4.43 \pm 0.30$ & $658 \pm 19$ & 2.9 & 1.0 \\
\hline$\# 11$ & $\begin{array}{l}\text { LR3043/50 }+100 \mathrm{phr} \\
\text { DMS-T22 (silicone-oil) }\end{array}$ & $61 \pm 2$ & $0.27 \pm 0.04$ & $1.51 \pm 0.14$ & $493 \pm 20$ & 3.0 & 1.3 \\
\hline & parts per hundred rubber & & & & & & \\
\hline
\end{tabular}

As seen in Table 2, the addition of copolymers and silicone oils significantly softens the otherwise stiff Elastosil LR3043/50 (Young's moduli calculated at 5\% strain are all considerably lower for samples with additives), due to the softening effect of the additives and the dilution of the heavily filled LR elastomer. Furthermore, all samples with additives have lower strains at breaking than the pure commercial elastomer - as anticipated -, since crosslinking density has been decreased and thus the stress that the elastically active chains can uphold is reduced. All samples, however, have strains at breaking higher than 200\%, which is an important requirement for DEs.

Figure 1 a) shows stress-strain curves for samples with copolymers which are covalently bonded to the networks, i.e. in theory there are no free species present in the networks. 
a)

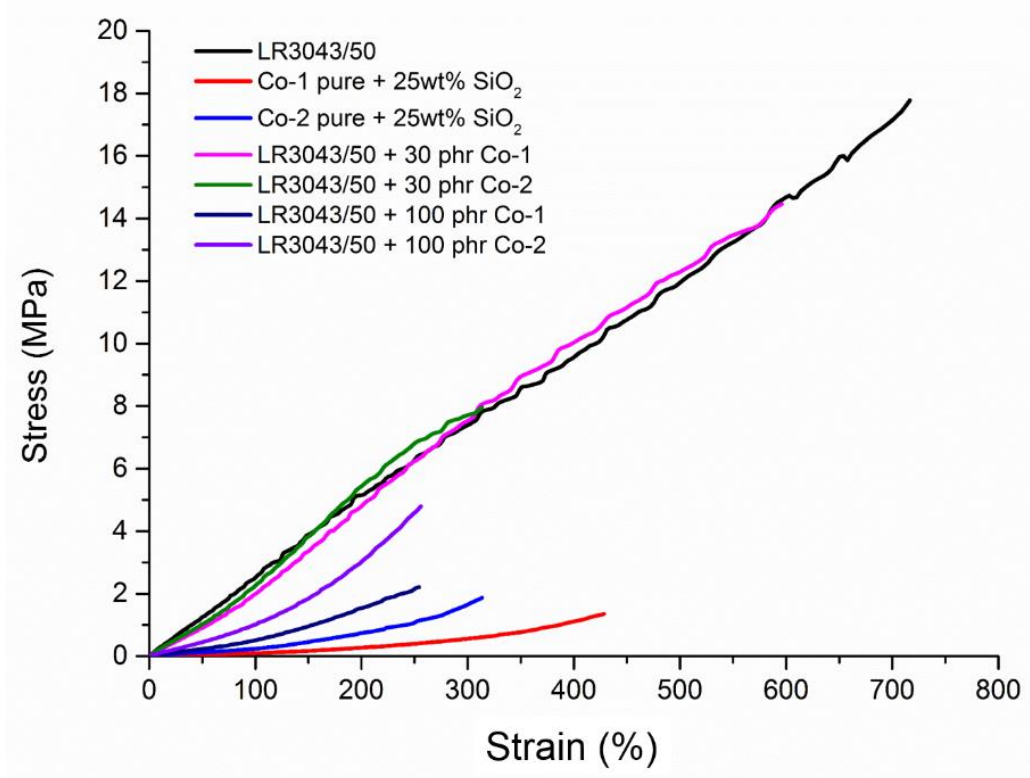

b)

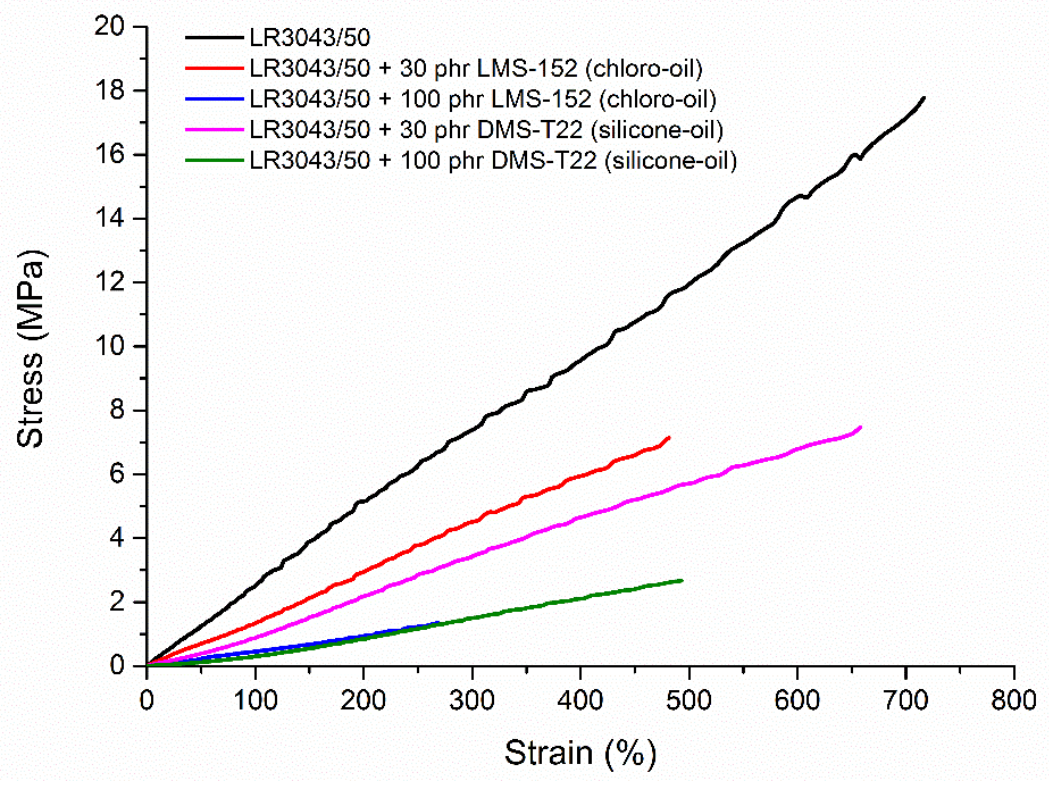

Figure 1. a): Stress-strain curves for samples with copolymers; b): Stress-strain curves for samples prepared with chloropropyl-functional and PDMS-based silicone oils. 
From Figure 1 a) it can be seen that the addition of copolymers to Elastosil LR3043/50 enables promising generator materials, since $30 \mathrm{phr}$ samples show similar stress-strain responses as pure Elastosil LR3043/50. The ultimate properties (strain at break), however, are somewhat reduced. It is clear, though, that optimum copolymer loading exists, since the $100 \mathrm{phr}$ samples show significantly reduced mechanical properties (both in terms of stress and strain at breaking). Elastomers based on pure copolymers are soft and quite stretchable, and therefore they are applicable as actuator materials. All samples with copolymers are seen to be strain-hardening, which is a much desired DE property, since this behaviour can suppress electromechanical instability (EMI). ${ }^{[30]}$

Stress-strain curves for samples containing chloropropyl- and PDMS-based silicone oils are shown in Figure 1 b) where is can be seen that both types of silicone oils soften the networks, as expected. At 30 phr the elastomers maintain suitable properties for generator applications, while at $100 \mathrm{phr}$ they are softened to an extent where they would be more suitable as actuator materials. Elastomers with oils do not experience significantly favourable strain-hardening, but on the other hand they do not strain-soften when approaching ultimate properties, and thus their mechanical properties remain favourable after the addition of oils. Tensile strength decreases in line with increasing oil content, and so the $100 \mathrm{phr}$ samples have low tensile strengths (stress at breaking). Chloropropylfunctional oils induce a lower tensile strength than PDMS-based silicone oil, probably due to slightly lower compatibility between LMS-152 (chloro-oil) and Elastosil LR3043/50 than the PDMS-based silicone oil has with Elastosil LR3043/50. Samples with the lowest tensile strength are also seen to have the lowest dielectric breakdown strengths (Table 2).

Pure elastomer Elastosil LR3043/50 has a very high dielectric breakdown strength of $181 \mathrm{~V} / \mu \mathrm{m}$, while elastomers based on pure copolymer (Co-1 or Co-2) have moderate electrical breakdown strengths, due to their softer nature and significantly lower filler content than Elastosil LR3043/50. The samples were not stretched during the measurements to allow for multiple measurements on the same film since stretched films usually tear completely upon electrical breakdown ${ }^{[26]}$ Adding silicone oils and copolymers to Elastosil LR3043/50 decreases the electrical breakdown strength of Elastosil LR3043/50 significantly, and electrical breakdown decreases in line with 
increasing content. Electrical breakdown strength is seen to depend strongly on the Young's modulus of the samples, with the softest samples having the lowest electrical breakdown strengths. This is in agreement with previously described results ${ }^{[4][22][36]}$, where electrical breakdown strength was found to scale linearly - or even exponentially - with the Young's modulus.

The dielectric permittivity of pure Elastosil LR3043/30 is $\varepsilon^{\prime}=2.7$ at $100 \mathrm{~Hz}$, while elastomers based on pure chloropropyl-functional copolymer Co-1 and Co-2 have dielectric permittivities of $\varepsilon^{\prime}=4.7$ and 5.1, respectively. The addition of chloropropyl-functional copolymers and oils increases the permittivity of Elastosil LR3043/50 significantly, up to $\varepsilon^{\prime}=5.6$ for sample 9 , which contains $100 \mathrm{phr}$ chloro-oil. Chloropropyl-functional silicone oil increases permittivity to a greater extent than copolymers achieve, which may be due to a higher concentration of chloropropyl groups and greater flexibility of polymer chains which are not covalently bonded to the network, thus leading to greater flexibility and polarisability. The addition of PDMS-based silicone oil does not, as expected, increase the permittivity of Elastosil LR3043/50, and the result lies within the experimentally expected variance.

A direct comparison, for example based only on dielectric permittivity, of the elastomers' performance with different compositions is difficult. Therefore, Sommer-Larsen and Larsen ${ }^{[5]}$ defined a universal expression which, through a single parameter, namely the figure of merit, $F_{\text {om }}$, can be used to evaluate the performance of different DE materials. The figure of merit depends on the dielectric permittivity, dielectric breakdown strength $\left(E_{\mathrm{B}}\right)$ and Young's modulus according to:

$F_{\mathrm{om}}=\frac{3 \varepsilon^{\prime} E_{B}{ }^{2}}{\mathrm{Y}}$

In Table 2, figures of merit for the different compositions are shown relative to the figure of merit for the reference elastomer Elastosil LR3043/50. Elastomers based on the pure copolymers Co-1 and Co-2 are seen to have the highest increases in the figure of merit compared to Elastosil LR3043/50. This is due to their high dielectric permittivity combined with their very soft nature, which in this case contributes significantly more than the moderate dielectric breakdown strength values. The addition of a chloropropyl-functional copolymer to Elastosil 
LR3043/50, however, does not increase the figure of merit, even though dielectric permittivity increases while the Young's modulus decreases. This means that the electrical breakdown strength reduction is greater than the permittivity and moduli contributions. The addition of chloropropyl-functional silicone oil increases the figure of merit and thereby DE performance by $10 \%$. A larger concentration of oil (100 phr), interestingly, does not increase performance more than the lower concentration (30 phr), because the $100 \mathrm{phr}$ sample has significantly lower dielectric breakdown strength. PDMS-based silicone oil increases the figure of merit by 10 and 30\%, respectively, for concentrations of 30 and $100 \mathrm{phr}$, respectively. In this case $100 \mathrm{phr}$ oil increases $F_{\text {om }}$ more than the lower concentration, due to the significant softening effect of PDMS-based silicone oil. It can therefore be deduced that PDMS-based silicone oil softens the elastomer to a greater extent than the chloropropyl-functional silicone oil, without compromising dielectric breakdown strength as much, due to greater compatibility.

\subsection{Properties after ageing experiments: mechanical properties}

Ageing experiments were carried out on an in-house-built frame, where $150 \mu \mathrm{m}$ thin samples remained stretched to $60 \%$ for one to three months, before they were released from the frames for characterisation. $60 \%$ strain was chosen since significant strain is imposed to elastomers above approximately $20 \%$ strain and $60 \%$ is thus well above the limit where changes to the elastomer may occur over time. Furthermore $60 \%$ strain is below a limit where tearing could occur. Tearing would in this case be undesired since the aim of the study was to investigate the internal (ageing) properties of the films over time as a result of long-term strain.

It has previously been shown that dielectric permittivity does not change drastically over time during such strain ageing experiments. ${ }^{[34]}$ In Figure 2 strains at breaking, before ('control' samples) and after the ageing experiments, are shown. The results are summarised further in Table 4 . The strain at breaking for the pure commercial elastomer Elastosil LR3043/50 (sample 1) is seen to decrease after ageing, although this phenomenon is not seen for all samples; sample 6 (LR3043/50 + $100 \mathrm{phr}$ Co-1), for example, experiences a significant increase in strain at breaking, from $269 \%$ to $661 \%$. Samples 7 (LR3043/50 + $100 \mathrm{phr}$ Co-2) and 9 (LR3043/50 + 100 phr chloro-oil) 
also exhibit this behaviour, perhaps due to the reduction of cross-linking density while maintaining significant cross-linked polymer chain strength (i.e. the chloropropyl-functional polymer chains may uphold stress while their mobility is strongly decreased).

Most importantly, however, all investigated compositions fulfilled the requirements of more than $200 \%$ strain at any given time during the ageing experiments. This property is important in relation to a product's reliability and its lifetime, in order to make sure that DE products do not experience mechanical failure as a first failure mode. 

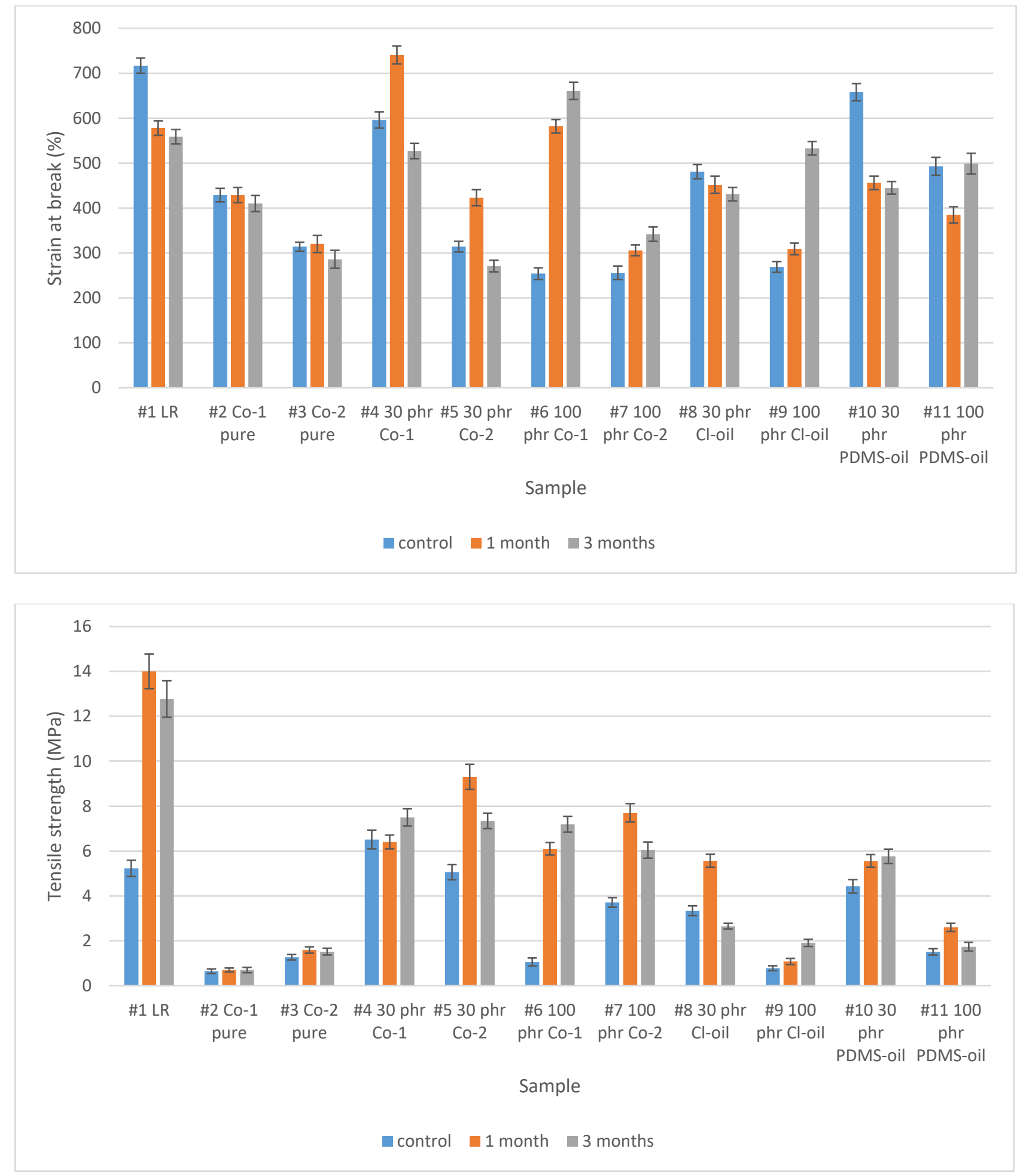

Figure 2. Top: Strain at breaking before and after ageing for one and three months; bottom: Tensile strengths before and after ageing for one and three months. 
Tensile strengths, before and after ageing, for one and three months are shown in Figure 2, and the results are summarised further in Table 4. There is no clear pattern between tensile strength and ageing, although most samples seem to experience increased tensile strength after one month of strain ageing, after which tensile strength decreases at further ageing for three months. This may be due to two phenomena occurring simultaneously. The first phenomenon is most likely small siloxanes and residual solvent leaving the elastomers ${ }^{[37]}$. This has previously been shown to significantly increase the Young's modulus and tensile strength of stretched elastomers. ${ }^{[34]}$ When the surface of an elastomer is broken upon straining, small molecules, consisting mainly of cyclic siloxanes, which are bi-products from the initial polymer synthesis, and residual solvent are able to diffuse out of the elastomer. The migration and evaporation of volatiles significantly hardens the elastomers, which can also be seen in Figure 3, where Young's moduli as a function of the strain timeframe are shown. The phenomenon is particularly evident for sample 1 (pure commercial elastomers Elastosil LR3043/50), sample 5 (LR3043/50 + 30 phr Co-2), sample 6 (LR3043/50 + 100 phr Co-1), sample 7 (LR3043/50 + 100 phr Co-2) and sample 8 (LR3043/50 + 30 phr chlorooil), all of which show significant increases in tensile strength and Young's moduli after one month of straining. After three months, tensile strength as well as Young's moduli dropped for most of the samples that showed increased values after one month. This is due to ageing effects, whereby properties deteriorate after long-term straining. Sample 6 (LR3043/50 + 100 phr Co-1), however, does not show any ageing effects after three months, and all samples with oils show a decreased Young's modulus after three months of strain. It is clear that samples containing oils exhibit similar behaviours, namely initial stiffening, due to the evaporation of small molecules, followed by ageing, which deteriorates mechanical properties. Most samples with copolymers also follow this trend, albeit not to the same extent. 

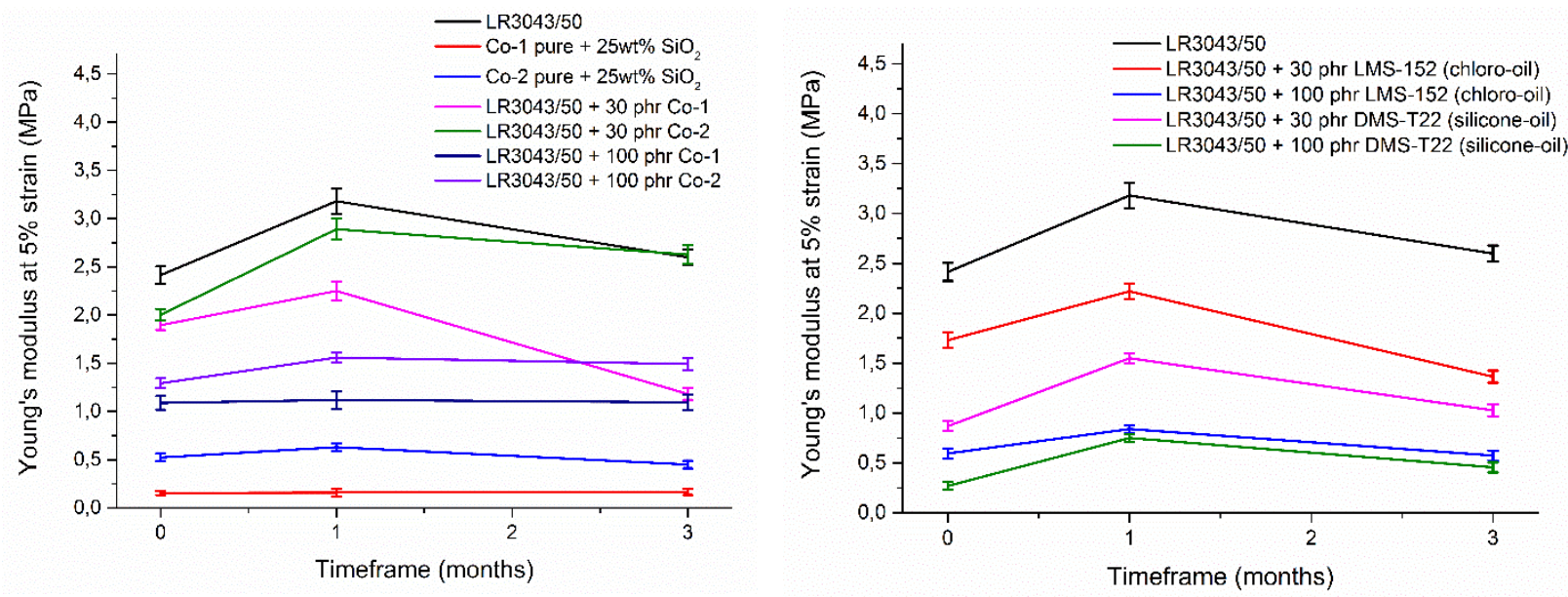

Figure 3. Young's modulus at 5\% strain after ageing for one and three months for left: Samples with copolymers and right: samples with oils.

Furthermore, the effect of oil concentration on mechanical properties upon ageing can be seen in Figure 4, where stress-strain curves for pure Elastosil LR3043/50 and Elastosil LR3043/50 containing 30 and 100 phr oil are shown. Overall, the commercial elastomer Elastosil LR3043/50 maintains its mechanical properties. After one month of ageing, hardening is seen in the fact that the volatiles, which act as plasticisers, have left the elastomer and the ultimate strain has reduced. After three months, there is no further significant ageing beyond what happened at one month. It is clear that sample 11, which contains 100 phr PDMS-based silicone oil, behaves differently upon ageing than pure Elastosil LR3043/50 and the low-oil concentration (30 phr) sample. The high concentration sample clearly ages more than the low concentration sample, where only minor differences in stressstrain behaviour are observed compared to the reference sample Elastosil LR3043/50. The $30 \mathrm{phr}$ sample, however, slightly hardens continuously throughout the three months, though the maximum extension of $>650 \%$ is lost within the first month. The chloropropyl-functional oil-containing samples behave somewhat differently to the PDMSbased silicone oil-containing samples. Contrary to its PDMS-based silicone oil counterpart, the $10 \mathrm{phr}$ chloropropyl-functional silicone softens after ageing, and a degree of extension is lost. The 100 phr chloropropylfunctional oil sample behaves differently to all of the other oil samples after three months of ageing. As the only sample, both its tensile strength and maximum strain increase after ageing. Chloropropyl-functional and PDMSbased silicone oil thus behave differently in the silicone matrix upon long-term straining, which might be due to 
the chloropropyl-functional silicone oil not having the same affinity for reinforcing silica particles in the elastomer as the PDMS-based silicone oil does. Therefore, silica particles in the chloropropyl-functional oil-containing samples are not affected by silicone oil and are plasticised to the same extent as the PDMS-based oil samples. Thus, silica particles are able to reinforce the network even better after age straining, since the chloropropylfunctional oil has had time to diffuse away from the silica particles (and probably phase-separate, to some extent) during the ageing experiment. Overall, it is clear that oil content plays a role in the ageing of silicone elastomers, and it is evident that high concentrations of silicone oils should be avoided for DEs with a desired long lifetime, due to significantly reduced mechanical properties and the tendency toward strain-softening behaviour over time - as observed most obviously for the $100 \mathrm{phr}$ chloropropyl-functional silicone oil sample. 


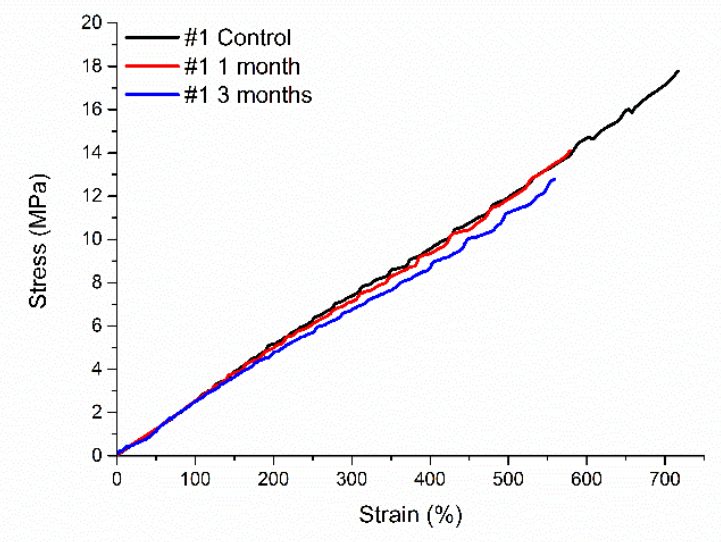

Stress-strain curve for \#1, LR3043/50
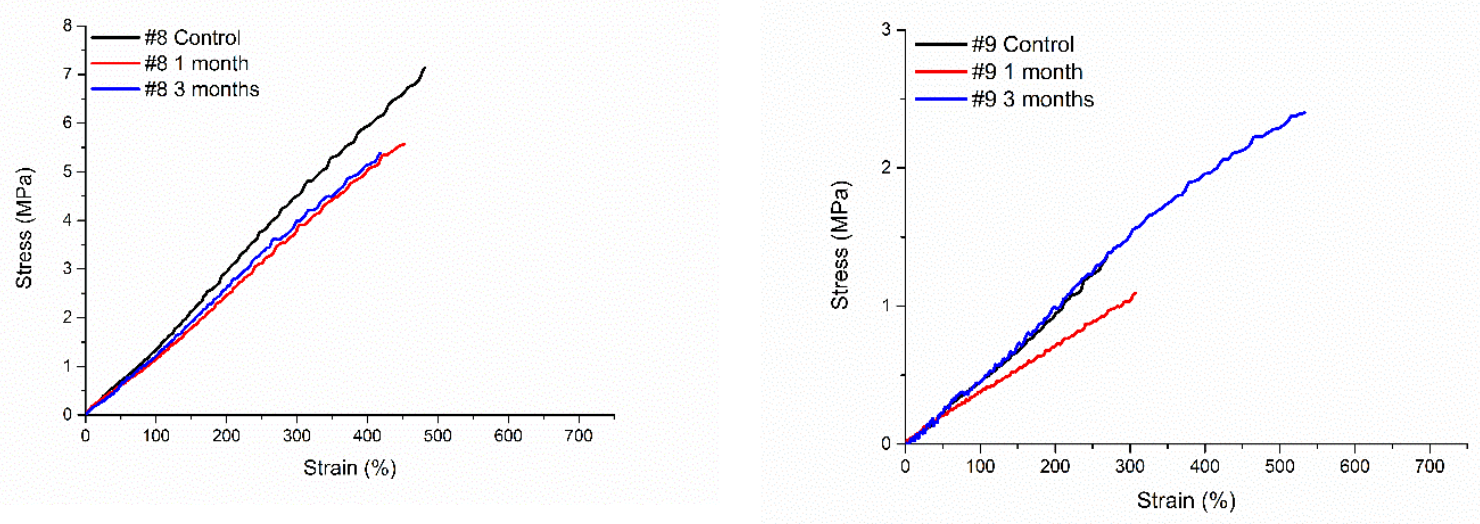

Stress-strain curve for \#8, LR3043/50+ 30 phr chloropropyl-functional silicone oil

Stress-strain curve for \#9 LR3043/50+ 100 phr chloropropylfunctional silicone oil
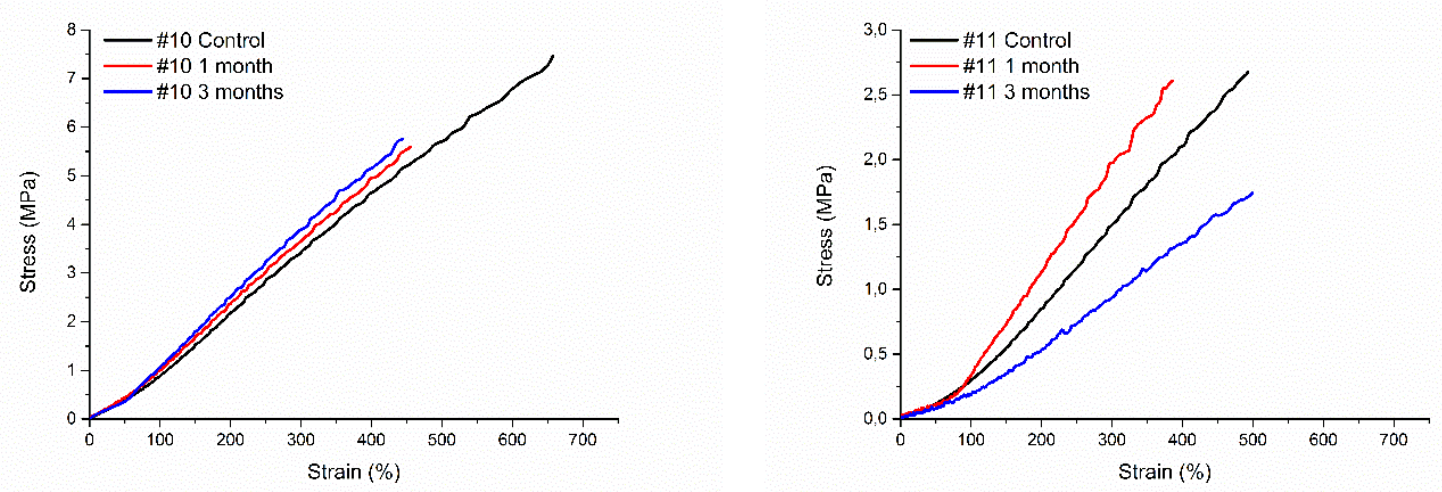

Stress-strain curve for \#10 LR3043/50+ 30 phr PDMSbased silicone oil

Stress-strain curve for \#11 LR3043/50+ 100 phr PDMS-based silicone oil

Figure 4. Stress strain curves, before and after ageing of samples with oils. 
For samples containing copolymers, the trend in stress-strain-related ageing is not so obvious (all results can be found in the supporting information), since elastomers based on pure Co-1 or Co-2 do not age significantly upon straining for one or three months. This may be due to these samples' inherent softness and lower filler content. Elastosil LR3043/50 samples with copolymers all age to some extent, whereby some age strongly and others only slightly. One of the samples with the most interesting behaviour is sample 4 (LR3043/50 + 30 phr Co-1), which fails completely after ageing (both one and three months), as seen in Figure 5, since it starts to show strainsoftening behaviour and significantly reduced tensile strength.

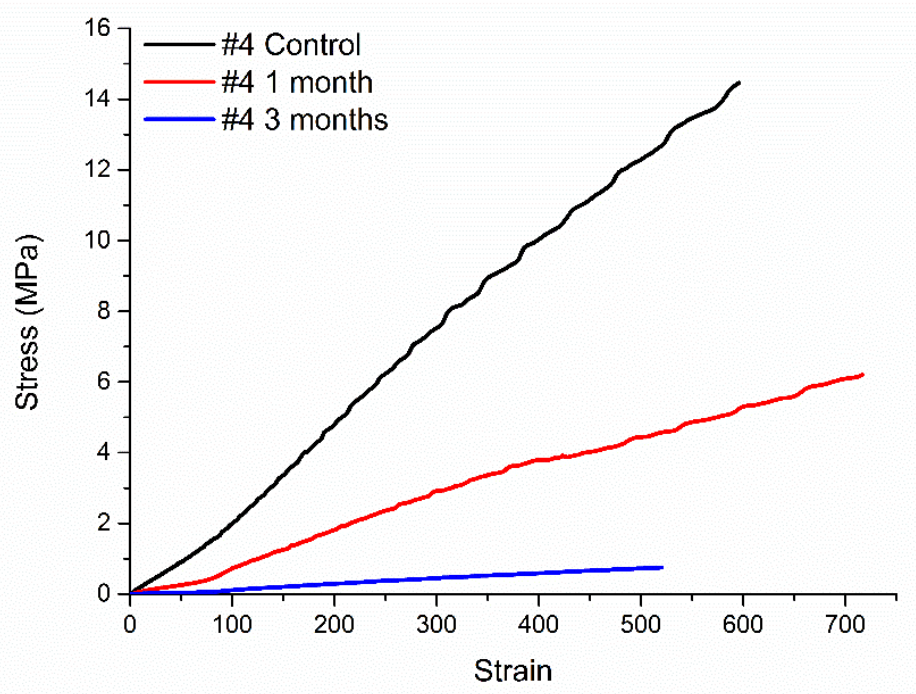

Figure 5. Stress-strain curves, before and after ageing, for sample \#4 ((LR3043/50 + $30 \mathrm{phr}$ Co-1).

Sample 6, which contains $100 \mathrm{phr}$ Co-1, also dramatically changes properties over time, albeit in a positive way this time, since its tensile strength and maximum strain increase significantly. This may again be due to the chloropropyl-functional nature, which acts in a similar way to the $100 \mathrm{phr}$ chloropropyl-functional silicone oil sample. Sample 7, which contains 100 phr Co-2, also gains in both tensile strength and maximum strain after ageing, but it loses its strain-hardening behaviour after three months of ageing, and its Young's modulus is constant up to its breaking point at a strain of approximately $325 \%$. 


\subsection{Properties after ageing experiments: electrical breakdown properties}

Since the mechanical properties of samples containing copolymers and oils were all affected in one way or another by the strain-ageing experiments, it is also expected that the dielectric breakdown strength of the samples will be affected. The average dielectric breakdown strength from eight breakdown tests on each sample is shown in Figure 6 and summarised further in Table 4.

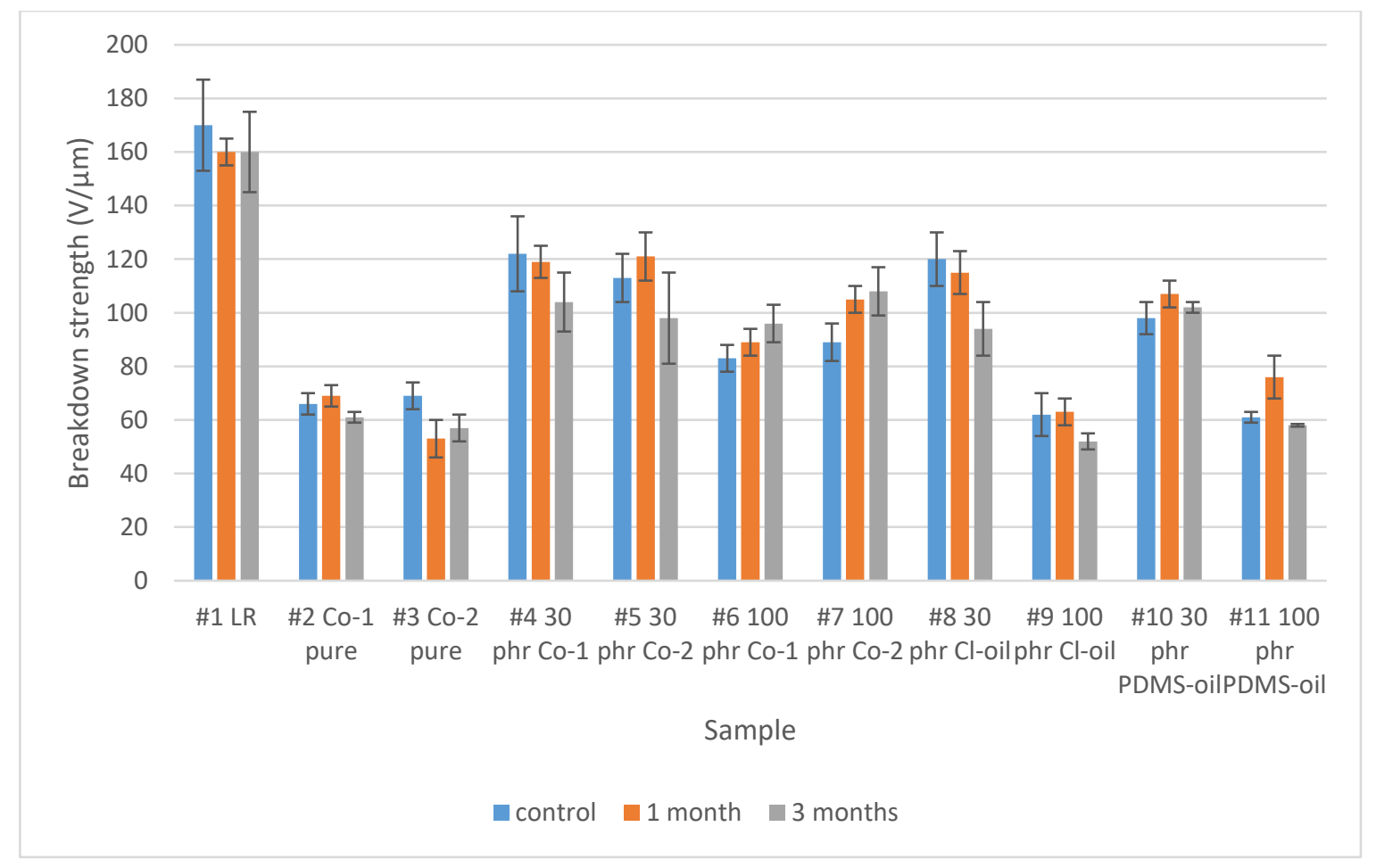

Figure 6. Dielectric breakdown strengths, before and after the ageing experiments.

Within the bounds of experimental uncertainty, all samples roughly maintain their electrical breakdown strength after ageing. There is, however, a trend for decreasing electrical breakdown strengths after three months of ageing, expect for samples 6 (100 phr Co-1) and 7 (100 phr Co-2). These decreasing and increasing trends closely follow the detected changes in Young's moduli upon ageing. 
In order to investigate the effect of ageing experiments on electrical breakdown distribution, Weibull analyses were performed. Weibull is one of the most used methods for lifetime analysis and can furthermore provide information about the homogeneity and electrical reliability of an elastomer.

The Weibull distribution function from Equation 1 can be linearised to give:

$\ln \left[-\ln \left(1-F\left(E_{B}\right)\right)\right]=\beta \cdot \ln \left(E_{B}\right)-\beta \cdot \ln (\eta)$

The shape parameter, $\beta$, is then equal to the slope of the regressed line. It is desirable to have as large a $\beta$-value as possible, since this means that the electrical breakdown values fall within a narrow range of voltages. A high $\beta$ value also gives an indication about homogeneity at the microscale, as the electrical breakdown strength measurement is very sensitive to imperfections. $\eta$ should also be as high as possible and is determined from the distribution at which $63 \%$ of the samples have broken down. The Weibull distribution results with $\beta, \eta$ and a linear regression value $\left(\mathrm{r}^{2}\right)$ are shown in Table 3, whereas the Weibull probability plots from which the parameters have been determined can be found in the supporting information. The probability plot for Elastosil LR3043/50 after three months of ageing shows two distributions, whereas the control sample and the sample after one month of ageing only show one distribution. This indicates that three months of ageing destroys locally the properties of the Elastosil LR3043/50 network and reduces local electrical breakdown strength. Many of the samples containing chloropropyl functionality show peculiar electrical breakdown behaviour in the Weibull probability plots, with two clearly separated distributions signifying two breakdown processes. This indicates that electrical breakdown in these samples occurs specifically as a result of the presence of the chloropropyl groups and less because of actual defects. Chloropropyl groups may act as local 'defects' in the samples, perhaps owing to the agglomeration of the polar chloropropyl groups. The two-parameter Weibull distribution was used despite the more complex shape for several of the samples since data could then be compared. Introducing another parameter to the Weibull distribution solely improved the results for some of the samples whereas other samples required a forth parameter. 
Table 3. Weibull parameters and $\mathrm{r}^{2}$, before and after the ageing experiments. Italic numbers indicate decreasing values compared to the control, and bold numbers indicate increasing values in this regard.

\begin{tabular}{|c|c|c|c|c|c|c|c|c|c|c|}
\hline \multirow[b]{2}{*}{ No } & \multirow[b]{2}{*}{ Composition } & \multicolumn{3}{|c|}{ Scale $(\eta)(\mathrm{V} / \mu \mathrm{m})$} & \multicolumn{3}{|c|}{ Shape $(\beta)$} & \multicolumn{3}{|l|}{$\mathrm{r}^{2}$} \\
\hline & & $\begin{array}{l}\text { contr } \\
\text { ol }\end{array}$ & $\begin{array}{l}\text { one } \\
\text { mont } \\
\mathrm{h}\end{array}$ & $\begin{array}{l}\text { three } \\
\text { months }\end{array}$ & control & $\begin{array}{l}\text { one } \\
\text { mont } \\
\mathrm{h}\end{array}$ & $\begin{array}{l}\text { three } \\
\text { months }\end{array}$ & $\begin{array}{l}\text { contr } \\
\text { ol }\end{array}$ & $\begin{array}{l}\text { one } \\
\text { mont } \\
\mathrm{h}\end{array}$ & $\begin{array}{l}\text { three } \\
\text { mont } \\
\text { hs }\end{array}$ \\
\hline$\# 1$ & LR3043/50 & 183 & 158 & 167 & 11 & 53 & 11 & 0.76 & 0.95 & 0.89 \\
\hline$\# 2$ & $\begin{array}{l}\mathrm{Co}-1 \text { pure }+25 \text { wt } \% \\
\mathrm{SiO}_{2}\end{array}$ & 68 & 66 & 62 & 20 & 14 & 41 & 0.95 & 0.87 & 0.66 \\
\hline$\# 3$ & $\begin{array}{l}\mathrm{Co}-2 \text { pure }+25 \mathrm{wt} \% \\
\mathrm{SiO}_{2}\end{array}$ & 71 & 56 & 59 & 16 & 9 & 12 & 0.79 & 0.84 & 0.91 \\
\hline \#4 & $\begin{array}{l}\text { LR3043/50 + } 30 \mathrm{phr} \\
\text { Co-1 }\end{array}$ & 127 & 119 & 109 & 11 & 19 & 11 & 0.75 & 0.95 & 0.75 \\
\hline \#5 & $\begin{array}{l}\text { LR3043/50 + } 30 \mathrm{phr} \\
\text { Co-2 }\end{array}$ & 117 & 118 & 106 & 15 & 20 & 6 & 0.76 & 0.85 & 0.95 \\
\hline \#6 & $\begin{array}{l}\text { LR3043/50 + } 100 \mathrm{phr} \\
\text { Co-1 }\end{array}$ & 85 & 82 & 100 & 19 & 25 & 13 & 0.82 & 0.88 & 0.98 \\
\hline$\# 7$ & $\begin{array}{l}\text { LR3043/50 + } 100 \mathrm{phr} \\
\text { Co-2 }\end{array}$ & 92 & 104 & 112 & 15 & 41 & 13 & 0.81 & 0.86 & 0.89 \\
\hline$\# 8$ & $\begin{array}{l}\text { LR3043/50 + } 30 \mathrm{phr} \\
\text { LMS-152 (chloro-oil) }\end{array}$ & 124 & 114 & 99 & 13 & 31 & 9 & 0.97 & 0.87 & 0.97 \\
\hline \#9 & $\begin{array}{l}\text { LR3043/50 + } 100 \mathrm{phr} \\
\text { LMS-152 (chloro-oil) }\end{array}$ & 65 & 61 & 53 & 8 & 26 & 23 & 0.88 & 0.88 & 0.82 \\
\hline$\# 10$ & $\begin{array}{l}\text { LR3043/50 + } 30 \mathrm{phr} \\
\text { DMS-T22 (silicone-oil) }\end{array}$ & 101 & 108 & 103 & 16 & 63 & 51 & 0.97 & 0.91 & 0.92 \\
\hline$\# 11$ & $\begin{array}{l}\text { LR3043/50 + } 100 \mathrm{phr} \\
\text { DMS-T22 (silicone-oil) }\end{array}$ & 62 & 73 & 58 & 26 & 27 & 123 & 0.97 & 0.63 & 0.78 \\
\hline
\end{tabular}

The Weibull distribution parameters show that strain-ageing experiments affect the reliability of the tested samples negatively as the scale parameter for most samples decreases. On the other hand, it can be seen from the shape parameters that most samples benefit from one month of ageing, since this leads to increases in $\beta$. This is probably due to the aforementioned removal of volatiles, which leads to more homogenous elastomers and higher Young's moduli. After three months of ageing, only four samples maintain this positive effect of volatile removal, and true ageing effects have therefore set in. Furthermore, $r^{2}$, the linear regression goodness-of-fit value, decreases after three months of ageing for approximately half of the samples with no clear trend. 


\subsection{Properties after the ageing experiments: figure of merit}

The figures of merit, normalised to the reference elastomer Elastosil LR3043/50 before and after the ageing experiments, are shown in Table 4. It is evident that the predicted performance of most elastomers improves after one month of aging, since normalised figure of merit values increase due to the small siloxanes and or solvent that have evaporated away from the elastomers and have thus increased dielectric breakdown strength. After three months of ageing, samples with high concentrations of oils (sample 9 and 11) show decreased predicted performance as a result of true ageing effects. Again, high concentrations of free species in the elastomers are shown to decrease overall DE properties significantly over time. The other samples' figures of merit after three months do not seem to follow any specific trend. 
Table 4. Summary of properties, before and after the ageing experiments. Italic numbers indicate decreasing values compared to the control, and bold numbers indicate increasing values in this regard.

\begin{tabular}{|c|c|c|c|c|c|c|c|c|c|c|c|c|c|c|c|c|}
\hline \multirow[b]{2}{*}{ No } & \multirow[b]{2}{*}{ Composition } & \multicolumn{3}{|c|}{ Breakdown $(\mathrm{V} / \mu \mathrm{m})$} & \multicolumn{3}{|c|}{$\mathrm{Y} @ 5 \%$ strain $(\mathrm{MPa})$} & \multicolumn{3}{|c|}{ Tensile strength (MPa) } & \multicolumn{3}{|c|}{ Strain@break (\%) } & \multicolumn{3}{|c|}{$\begin{array}{l}\text { Normalised figure of } \\
\text { merit }\end{array}$} \\
\hline & & $\begin{array}{l}\text { contr } \\
\text { ol }\end{array}$ & $\begin{array}{l}\text { one } \\
\text { mont } \\
\mathrm{h}\end{array}$ & $\begin{array}{l}\text { three } \\
\text { months }\end{array}$ & $\begin{array}{l}\text { contr } \\
\text { ol }\end{array}$ & $\begin{array}{l}\text { one } \\
\text { mont } \\
\mathrm{h}\end{array}$ & $\begin{array}{l}\text { three } \\
\text { months }\end{array}$ & $\begin{array}{l}\text { contr } \\
\text { ol }\end{array}$ & $\begin{array}{l}\text { one } \\
\text { mont } \\
\mathrm{h}\end{array}$ & $\begin{array}{l}\text { three } \\
\text { months }\end{array}$ & $\begin{array}{l}\text { contr } \\
\text { ol }\end{array}$ & $\begin{array}{l}\text { one } \\
\text { mont } \\
\mathrm{h}\end{array}$ & $\begin{array}{l}\text { three } \\
\text { months }\end{array}$ & $\begin{array}{l}\text { contro } \\
1\end{array}$ & $\begin{array}{l}\text { one } \\
\text { mont } \\
\mathrm{h}\end{array}$ & $\begin{array}{l}\text { three } \\
\text { months }\end{array}$ \\
\hline$\# 1$ & LR3043/50 & $\begin{array}{l}181 \pm \\
6\end{array}$ & $\begin{array}{l}160 \pm \\
5\end{array}$ & $\begin{array}{l}160 \pm 1 \\
5\end{array}$ & $\begin{array}{l}2.41 \pm \\
0.09\end{array}$ & $\begin{array}{l}3.18 \pm \\
0.13\end{array}$ & $\begin{array}{l}2.60 \pm 0 \\
.08\end{array}$ & $\begin{array}{l}5.23 \pm \\
0.36\end{array}$ & $\begin{array}{l}14.0 \pm \\
0.77\end{array}$ & $\begin{array}{l}12.8 \pm 0 \\
.81\end{array}$ & $\begin{array}{l}717 \pm \\
17\end{array}$ & $\begin{array}{l}578 \pm \\
16\end{array}$ & $\begin{array}{l}559 \pm 1 \\
4\end{array}$ & 1 & 1 & 1 \\
\hline$\# 2$ & $\begin{array}{l}\mathrm{Co}-1 \text { pure }+25 \text { wt } \% \\
\mathrm{SiO}_{2}\end{array}$ & $66 \pm 4$ & $69 \pm 4$ & $61 \pm 2$ & $\begin{array}{l}0.15 \pm \\
0.02\end{array}$ & $\begin{array}{l}0.16 \pm \\
0.04\end{array}$ & $\begin{array}{l}\mathbf{0 . 1 7} \pm 0 \\
.03\end{array}$ & $\begin{array}{l}0.65 \pm \\
0.10\end{array}$ & $\begin{array}{l}0.70 \pm \\
0.09\end{array}$ & $\begin{array}{l}0.70 \pm 0 \\
.12\end{array}$ & $\begin{array}{l}429 \pm \\
15\end{array}$ & $\begin{array}{l}429 \pm \\
17\end{array}$ & $\begin{array}{l}410 \pm 1 \\
8\end{array}$ & 3.7 & 6.4 & 4.0 \\
\hline \#3 & $\begin{array}{l}\mathrm{Co}-2 \text { pure }+25 \mathrm{wt} \% \\
\mathrm{SiO}_{2}\end{array}$ & $69 \pm 5$ & $53 \pm 7$ & $57 \pm 5$ & $\begin{array}{l}0.52 \pm \\
0.04\end{array}$ & $\begin{array}{l}0.63 \pm \\
0.04\end{array}$ & $\begin{array}{l}0.45 \pm 0 \\
.04\end{array}$ & $\begin{array}{l}1.27 \pm \\
0.12\end{array}$ & $\begin{array}{l}1.59 \pm \\
0.14\end{array}$ & $\begin{array}{l}1.52 \pm 0 \\
.15\end{array}$ & $\begin{array}{l}314 \pm \\
10\end{array}$ & $\begin{array}{l}320 \pm \\
19\end{array}$ & $\begin{array}{l}286 \pm 2 \\
0\end{array}$ & 1.3 & 1.0 & 1.4 \\
\hline \#4 & $\begin{array}{l}\text { LR3043/50 + } 30 \text { phr } \\
\text { Co-1 }\end{array}$ & $\begin{array}{l}122 \pm \\
14\end{array}$ & $\begin{array}{l}119 \pm \\
6\end{array}$ & $\begin{array}{l}104 \pm 1 \\
1\end{array}$ & $\begin{array}{l}1.90 \pm \\
0.05\end{array}$ & $\begin{array}{l}2.25 \pm \\
0.10\end{array}$ & $\begin{array}{l}1.18 \pm 0 \\
.06\end{array}$ & $\begin{array}{l}6.51 \pm \\
0.42\end{array}$ & $\begin{array}{l}6.40 \pm \\
0.31\end{array}$ & $\begin{array}{l}7.50 \pm 0 \\
.38\end{array}$ & $\begin{array}{l}596 \pm \\
18\end{array}$ & $\begin{array}{l}741 \pm \\
20\end{array}$ & $\begin{array}{l}527 \pm 1 \\
7\end{array}$ & 0.7 & 0.9 & 1.1 \\
\hline \#5 & $\begin{array}{l}\text { LR3043/50 + } 30 \text { phr } \\
\text { Co-2 }\end{array}$ & $\begin{array}{l}113 \pm \\
9\end{array}$ & $\begin{array}{l}121 \pm \\
9\end{array}$ & $98 \pm 17$ & $\begin{array}{l}2.00 \pm \\
0.06\end{array}$ & $\begin{array}{l}2.89 \pm \\
0.11\end{array}$ & $\begin{array}{l}2.63 \pm 0 \\
.10\end{array}$ & $\begin{array}{l}5.06 \pm \\
0.34\end{array}$ & $\begin{array}{l}9.30 \pm \\
0.56\end{array}$ & $\begin{array}{l}7.34 \pm 0 \\
.34\end{array}$ & $\begin{array}{l}314 \pm \\
12\end{array}$ & $\begin{array}{l}423 \pm \\
18\end{array}$ & $\begin{array}{l}271 \pm 1 \\
3\end{array}$ & 0.7 & 0.8 & 0.5 \\
\hline \#6 & $\begin{array}{l}\text { LR3043/50 + } 100 \mathrm{phr} \\
\text { Co-1 }\end{array}$ & $83 \pm 5$ & $89 \pm 5$ & $96 \pm 7$ & $\begin{array}{l}1.09 \pm \\
0.07\end{array}$ & $\begin{array}{l}1.12 \pm \\
0.09\end{array}$ & $\begin{array}{l}1.10 \pm 0 \\
.08\end{array}$ & $\begin{array}{l}1.06 \pm \\
0.18\end{array}$ & $\begin{array}{l}6.10 \pm \\
0.28\end{array}$ & $\begin{array}{l}7.19 \pm 0 \\
.35\end{array}$ & $\begin{array}{l}254 \pm \\
13\end{array}$ & $\begin{array}{l}582 \pm \\
15\end{array}$ & $\begin{array}{l}661 \pm 1 \\
9\end{array}$ & 0.6 & 1.1 & 1.0 \\
\hline \#7 & $\begin{array}{l}\text { LR3043/50 + } 100 \mathrm{phr} \\
\text { Co-2 }\end{array}$ & $89 \pm 7$ & $\begin{array}{l}105 \pm \\
5\end{array}$ & $108 \pm 9$ & $\begin{array}{l}1.29 \pm \\
0.05\end{array}$ & $\begin{array}{l}1.56 \pm \\
0.05\end{array}$ & $\begin{array}{l}1.49 \pm 0 \\
.06\end{array}$ & $\begin{array}{l}3.71 \pm \\
0.21\end{array}$ & $\begin{array}{l}7.70 \pm \\
0.41\end{array}$ & $\begin{array}{l}6.04 \pm 0 \\
.36\end{array}$ & $\begin{array}{l}256 \pm \\
15\end{array}$ & $\begin{array}{l}306 \pm \\
12\end{array}$ & $\begin{array}{l}342 \pm 1 \\
6\end{array}$ & 0.6 & 1.2 & 1.1 \\
\hline$\# 8$ & $\begin{array}{l}\text { LR3043/50 + } 30 \mathrm{phr} \\
\text { LMS-152 (chloro-oil) }\end{array}$ & $\begin{array}{l}120 \pm \\
10\end{array}$ & $\begin{array}{l}115 \pm \\
8\end{array}$ & $94 \pm 10$ & $\begin{array}{l}1.73 \pm \\
0.08\end{array}$ & $\begin{array}{l}2.22 \pm \\
0.08\end{array}$ & $\begin{array}{l}1.36 \pm 0 \\
.06\end{array}$ & $\begin{array}{l}3.34 \pm \\
0.22\end{array}$ & $\begin{array}{l}5.57 \pm \\
0.29\end{array}$ & $\begin{array}{l}2.65 \pm 0 \\
.13\end{array}$ & $\begin{array}{l}481 \pm \\
16\end{array}$ & $\begin{array}{l}452 \pm \\
19\end{array}$ & $\begin{array}{l}431 \pm 1 \\
5\end{array}$ & 1.0 & 1.2 & 1.1 \\
\hline$\# 9$ & $\begin{array}{l}\text { LR3043/50 + } 100 \mathrm{phr} \\
\text { LMS-152 (chloro-oil) }\end{array}$ & $62 \pm 8$ & $63 \pm 5$ & $52 \pm 3$ & $\begin{array}{l}0.60 \pm \\
0.05\end{array}$ & $\begin{array}{l}0.84 \pm \\
0.04\end{array}$ & $\begin{array}{l}0.57 \pm 0 \\
.05\end{array}$ & $\begin{array}{l}0.78 \pm \\
0.11\end{array}$ & $\begin{array}{l}1.08 \pm \\
0.14\end{array}$ & $\begin{array}{l}1.91 \pm 0 \\
.16\end{array}$ & $\begin{array}{l}269 \pm \\
12\end{array}$ & $\begin{array}{l}309 \pm \\
13\end{array}$ & $\begin{array}{l}533 \pm 1 \\
5\end{array}$ & 1.0 & 1.2 & 1.0 \\
\hline$\# 10$ & $\begin{array}{l}\text { LR3043/50 + } 30 \mathrm{phr} \\
\begin{array}{l}\text { DMS-T22 (silicone- } \\
\text { oil) }\end{array}\end{array}$ & $98 \pm 6$ & $\begin{array}{l}107 \pm \\
5\end{array}$ & $102 \pm 2$ & $\begin{array}{l}0.87 \pm \\
0.05\end{array}$ & $\begin{array}{l}1.55 \pm \\
0.06\end{array}$ & $\begin{array}{l}1.03 \pm 0 \\
.06\end{array}$ & $\begin{array}{l}4.43 \pm \\
0.30\end{array}$ & $\begin{array}{l}5.56 \pm \\
0.28\end{array}$ & $\begin{array}{l}5.76 \pm 0 \\
.32\end{array}$ & $\begin{array}{l}658 \pm \\
19\end{array}$ & $\begin{array}{l}456 \pm \\
15\end{array}$ & $\begin{array}{l}445 \pm 1 \\
4\end{array}$ & 0.9 & 1.0 & 1.1 \\
\hline \#11 & $\begin{array}{l}\text { LR3043/50 + } 100 \mathrm{phr} \\
\begin{array}{l}\text { DMS-T22 (silicone- } \\
\text { oil) }\end{array}\end{array}$ & $61 \pm 2$ & $76 \pm 8$ & $58 \pm 0.5$ & $\begin{array}{l}0.27 \pm \\
0.04\end{array}$ & $\begin{array}{l}0.75 \pm \\
0.04\end{array}$ & $\begin{array}{l}0.46 \pm 0 \\
.05\end{array}$ & $\begin{array}{l}1.51 \pm \\
0.14\end{array}$ & $\begin{array}{l}2.60 \pm \\
0.18\end{array}$ & $\begin{array}{l}1.74 \pm 0 \\
.19\end{array}$ & $\begin{array}{l}493 \pm \\
20\end{array}$ & $\begin{array}{l}385 \pm \\
18\end{array}$ & $\begin{array}{l}499 \pm 2 \\
3\end{array}$ & 1.1 & 1.1 & 0.8 \\
\hline
\end{tabular}




\section{Conclusion}

Soft silicone elastomers were prepared by using a strong commercial elastomer, Elastosil LR3043/50, mixed with a choice of cross-linkable chloropropyl-functional copolymers, chloropropyl-functional silicone oil or PDMSbased silicone oil. Elastomer samples with different concentrations of soft fillers were subjected to static straining of $60 \%$ for up to three months, and characteristic dielectric elastomer properties, such as Young's modulus, strain at breaking and dielectric breakdown strength, were analysed before and after the strain ageing experiments. The results showed that adding soft functional fillers to the Elastosil LR3043/50 elastomer influenced its properties after ageing. One month of strain seemed to benefit most compositions, since small volatiles were allowed to escape from the elastomers during straining. This phenomenon enhanced the Young's moduli, tensile strength and strain at breaking, as well as dielectric breakdown strength, for the majority of the samples. After three months of straining, true ageing effects were seen for most of the samples, although some samples, such as those containing chloropropyl groups, seemed to benefit from three months of strain treatment, with significantly increased Young's moduli, strain at breaking and electrical breakdown strengths as a consequence. This might be due to the migration of chloropropyl groups away from silica particles which are then able to reinforce the elastomers significantly. High concentrations of oils, whether chloropropyl-functional or PDMS-based, should be avoided, since this induces significantly reduced electrical breakdown strengths and mechanical stability, both before and after strain ageing.

\section{Experimental}

\subsection{Materials and sample preparation}

Silicone oil, DMS-T22 $\left(\bar{M}_{w} \approx 9,430 \mathrm{~g} \mathrm{~mol}^{-1}\right)$ and LMS-152 $\left(\bar{M}_{w} \approx 9,000 \mathrm{~g} \mathrm{~mol}^{-1}\right.$, with chloropropyl-functional groups), and a hydride-functional cross-linker, HMS301 (8-functional (8f), $\mathrm{M}_{\mathrm{w}}=1950 \mathrm{~g} / \mathrm{mol}$ ), were acquired from Gelest Inc. Elastosil@ LR3043/50 (Wacker Chemie AG) is a two-component silicone comprising a component A and a component B mixed in a 1:1 ratio. Inhibitor Pt88 and the solvent Belsil were also acquired from Wacker Chemie AG. The platinum cyclovinylmethyl siloxane complex catalyst (511) was purchased from Hanse Chemie, 
while silicon dioxide amorphous hexamethyldisilazane-treated particles (SIS6962.0) were purchased from Fluorochem. Co-1 and Co-2 were synthesised according to previously described procedures. ${ }^{[9]}$ Two types of allylterminated chloropropyl-functional copolymers of around 26,000-29,000 $\mathrm{g} \mathrm{mol}^{-1}$ were prepared: one copolymer contained chloropropyl groups, with $1200 \mathrm{~g} \mathrm{~mol}^{-1}$ dimethylsiloxane spacer units between each group (Co-1), and the other copolymer contained chloropropyl groups, with $580 \mathrm{~g} \mathrm{~mol}^{-1}$ dimethylsiloxane spacers between the functional groups (Co-2). Co-2 thus contains approximately double the amount of chloropropyl groups than Co1.

\subsubsection{General procedure: films with Co-1 or Co-2}

Co-1 or Co-2 and an 8-functional cross-linker were mixed with treated silica particles (25 wt $\%)$ and an inhibitor (1 wt\%, Pt88) and then treated on a FlackTek Inc. DAC 150.1 FVZ-K SpeedMixer ${ }^{\mathrm{TM}}$. The platinum catalyst (1.5 ppm) was added thereafter, and the mixture was then speed-mixed once more. The mixture was coated as $150 \mu \mathrm{m}$ films on a glass substrate and cured at $80^{\circ} \mathrm{C}$ for 2 hours.

\subsubsection{General procedure: elastomer synthesis with soft fillers}

An appropriate amount of Co-1, Co-2 or silicone oils was mixed with the first component (A) of the commercial silicone Elastosil@ LR3043/50 and solvent (Belsil) using a SpeedMixer. The second elastomer component (B) and inhibitor were then added, and the mixture was speed-mixed once more. The mixture was then coated as thin films, using a doctor blade of $150 \mu \mathrm{m}$ thickness on a glass substrate, and then cured at $115^{\circ} \mathrm{C}$ for 1 hour. The different sample composition quantities can be seen in Table 5. 
Table 5. Compositions and quantities of the samples prepared with the soft filler.

\begin{tabular}{|c|c|c|c|c|c|c|c|c|c|c|c|}
\hline No & Composition & $\begin{array}{l}\mathrm{SiO}_{2} \\
(\mathrm{~g})\end{array}$ & $\begin{array}{l}\text { Co-1 (2f, } \\
M_{w}=260 \\
00 \quad g \\
\left.\mathrm{~mol}^{-1}\right) \\
(\mathrm{g})\end{array}$ & $\begin{array}{l}\text { Co-2 (2f, } \\
M_{w}= \\
29000 \mathrm{~g} \\
\left.\mathrm{~mol}^{-1}\right) \\
(\mathrm{g})\end{array}$ & $\begin{array}{l}\text { HMS301 } \\
(8 \mathrm{f}, \\
\mathrm{M}_{\mathrm{w}}=1950 \\
\left.\mathrm{~g} \quad \mathrm{~mol}^{-1}\right) \\
(\mathrm{g}) \mathrm{r}=2\end{array}$ & $\begin{array}{l}\text { Inhibitor } \\
(0.5 \%) \\
(\mathrm{g})\end{array}$ & $\begin{array}{l}\text { LR3043/ } \\
\text { 50A (g) }\end{array}$ & $\begin{array}{l}\text { LR3043/ } \\
\text { 50B }(\mathrm{g})\end{array}$ & $\begin{array}{l}\text { Belsil } \\
\text { solven } \\
\mathrm{t}(\mathrm{g})\end{array}$ & $\begin{array}{l}\text { LMS- } \\
152 \\
\text { (chlor } \\
\text { o-oil) } \\
\text { (g) }\end{array}$ & $\begin{array}{l}\text { DMS- } \\
\text { T22 } \\
\text { (silicone } \\
\text {-oil) (g) }\end{array}$ \\
\hline$\# 1$ & LR3043/50 & - & - & - & - & - & 5 & 5 & 5 & - & - \\
\hline$\# 2$ & $\begin{array}{l}\mathrm{Co}-1 \text { pure }+25 \text { wt } \% \\
\mathrm{SiO}_{2}\end{array}$ & 3 & 8.6747 & - & 0.3253 & 0.045 & - & - & - & - & - \\
\hline \#3 & $\begin{array}{l}\mathrm{Co}-2 \text { pure }+25 \text { wt } \% \\
\mathrm{SiO}_{2}\end{array}$ & 3 & - & 8.7073 & 0.2927 & 0.045 & - & - & - & - & - \\
\hline \#4 & $\begin{array}{l}\text { LR3043/50 + } 30 \text { phr Co- } \\
1\end{array}$ & - & 2.8916 & - & 0.1084 & 0.015 & 5 & 5 & 3 & - & - \\
\hline \#5 & $\begin{array}{l}\text { LR3043/50 + } 30 \text { phr Co- } \\
2\end{array}$ & - & - & 2.9024 & 0.0976 & 0.015 & 5 & 5 & 3 & - & - \\
\hline \#6 & $\begin{array}{l}\text { LR3043/50 + } 100 \text { phr } \\
\text { Co-1 }\end{array}$ & - & 5.7832 & - & 0.2168 & 0.030 & 3 & 3 & - & - & - \\
\hline \#7 & $\begin{array}{l}\text { LR3043/50 + } 100 \text { phr } \\
\text { Co-2 }\end{array}$ & - & - & 5.8048 & 0.1952 & 0.030 & 3 & 3 & - & - & - \\
\hline \#8 & $\begin{array}{l}\text { LR3043/50 + } 30 \text { phr } \\
\text { LMS-152 (chloro-oil) }\end{array}$ & - & - & - & - & - & 5 & 5 & 3 & 3 & - \\
\hline \#8 & $\begin{array}{l}\text { LR3043/50+100 phr } \\
\text { LMS-152 (chloro-oil) }\end{array}$ & - & - & - & - & - & 5 & 5 & - & 10 & - \\
\hline$\# 10$ & $\begin{array}{l}\text { LR3043/50 + } 30 \mathrm{phr} \\
\text { DMS-T22 (silicone-oil) }\end{array}$ & - & - & - & - & - & 5 & 5 & 3 & - & 3 \\
\hline \#11 & $\begin{array}{l}\text { LR3043/50 + } 100 \mathrm{phr} \\
\text { DMS-T22 (silicone-oil) }\end{array}$ & - & - & - & - & - & 5 & 5 & - & - & 10 \\
\hline
\end{tabular}




\subsection{Strain-ageing of samples}

The samples were strained on an in-house-built frame. The films were $130 \mathrm{~mm}$ in width and $350 \mathrm{~mm}$ in length. In order to strain the films successfully, both ends of the films were rolled with metal rods to prevent slippage of the stretched films, which were stretched to $60 \%$. The metal rods, together with the stretched films, were then attached to the frame. The films were covered by ETFE foils (50 $\mu \mathrm{m}$ thickness) to prevent contamination. Finally, the stretched films were stored for one month and three months, before they were released for further characterisations.

\subsection{Instrumentation}

\subsubsection{Electrical Breakdown measurements}

Electrical breakdown measurements were performed on an in-house-built device based on international standards (IEC 60243-1 (1998) and IEC 60243-2 (2001)). The initial thicknesses of the films before straining were determined with a Leica DMLB microscope with a USB Thorlabs 2.0 digital camera, and with multiple determinations along the cross-section. The thickness of the stretched film (which can be seen in the supporting

information) was calculated as $t_{1}=\frac{t_{0}}{\lambda}$, where $t_{0}$ is the initial thickness and $\lambda$ is the stretch ratio. The distance between the two spherical electrodes $(\varnothing=20 \mathrm{~mm})$ was set, according to sample thickness, with a micrometre stage and gauge. An indent of less than 3\% of sample thickness was added to ensure that the spheres were in contact with the sample. A step-wise increasing voltage was applied (50-100 V/step) at a rate of 0.5-1.0 step/s. Each sample was subjected to eight breakdown measurements, and an average of the values was indicated as the electrical breakdown strength of the sample. Data were then fitted to Weibull distribution and plotted. The electrical breakdown measurements were performed on non-stretched samples after releasing from frames. 
4.3.2. Young's modulus and tensile strength measurements

Uniaxial extensional rheology was performed on the series of elastomer films in order to determine the Young's modulus and tensile strength, as described by Zhang et al. ${ }^{[38]}$ The stress-strain curves of films were tested at RT by ARESG2 rheometer using SER2 geometry. The sample of $20 \mathrm{~mm}$ length and $6 \mathrm{~mm}$ width was placed between two drums and initially separated by a distance of $12.7 \mathrm{~mm}$. The test specimen was elongated uniaxially at steady Hencky strain rate of $0.01\left(\mathrm{~s}^{-1}\right)$ until sample failure at the middle part. Each composition was subjected to four tensile measurements which were then averaged. Young's moduli were obtained from the tangent of the stressstrain curves at $5 \%$ strain.

\section{Acknowledgements}

The authors gratefully acknowledge the financial support of the Danish Council for Independent Research, Innovationsfonden Denmark and the Ministry of Education of Malaysia and Universiti Malaysia Pahang.

\section{References}

[1] R. Pelrine, R. Kornbluh, Q. Pei, J. Joseph, Science 2000, 287, 836.

[2] X. Zhang, C. Löwe, M. Wissler, B. Jähne, G. Kovacs, Adv. Eng. Mater. 2005, 7, 361.

[3] F.B. Madsen, A.E. Daugaard, S. Hvilsted, A.L. Skov, Macromol. Rapid Commun. 2016, 37, 378.

[4] M. Kollosche, H. Stoyanov, H. Ragusch, S. Risse, A. Becker, G. Kofod, 2010 10th IEEE Int. Conf. Solid Dielectr. 2010, 1.

[5] P. Sommer-Larsen, A.L. Larsen, Proc. SPIE 2004, 5385, 68.

[6] S. Vudayagiri, M.D. Junker, A.L. Skov, Polym. J. 2013, 45, 871.

[7] B. Kussmaul, S. Risse, G. Kofod, R. Waché, M. Wegener, D.N. McCarthy, H. Krüger, R. Gerhard, Adv. Funct. Mater. 2011, 21, 4589.

[8] F.B. Madsen, A.E. Daugaard, S. Hvilsted, M.Y. Benslimane, A.L. Skov, Smart Mater. Struct. 2013, 22, 104002.

[9] F.B. Madsen, I. Javakhishvili, R.E. Jensen, A.E. Daugaard, S. Hvilsted, A.L. Skov, Polym. Chem. 2014, 5,7054 .

[10] A. Bele, M. Cazacu, C. Racles, G. Stiubianu, D. Ovezea, M. Ignat, Adv. Eng. Mater. 2015, 17, 1302.

[11] F.B. Madsen, A.E. Daugaard, C. Fleury, S. Hvilsted, A.L. Skov, RSC Adv. 2014, 4, 6939.

[12] S.M. Ha, W. Yuan, Q. Pei, R. Pelrine, S. Stanford, Adv. Mater. 2006, 18, 887. 
[13] S.M. Ha, W. Yuan, Q. Pei, R. Pelrine, S. Stanford, Smart Mater. Struct. 2007, 16, S280.

[14] P. Brochu, H. Stoyanov, X. Niu, Q. Pei, Smart Mater. Struct. 2013, 22, 055022.

[15] L. Yu, F.B. Madsen, S. Hvilsted, A.L. Skov, Proc. SPIE 2015, 9430, 94300T.

[16] L. Yu, F.B. Madsen, S. Hvilsted, A.L. Skov, RSC Adv. 2015, 5, 49739.

[17] J. Goff, S. Sulaiman, B. Arkles, J.P. Lewicki, Adv. Mater. 2016, n/a.

[18] F. Carpi, G. Gallone, F. Galantini, D. De Rossi, Adv. Funct. Mater. 2008, 18, 235.

[19] H. Liu, L. Zhang, D. Yang, N. Ning, Y. Yu, L. Yao, B. Yan, M. Tian, J. Phys. D. Appl. Phys. 2012, 45, 485303.

[20] S. Risse, B. Kussmaul, H. Krüger, G. Kofod, Adv. Funct. Mater. 2012, 22, 3958.

[21] F.B. Madsen, L. Yu, S. Hvilsted, A.L. Skov, Proc. SPIE 2015, 9430, 94301D.

[22] S. Vudayagiri, S. Zakaria, L. Yu, S.S. Hassouneh, M. Benslimane, A.L. Skov, Smart Mater. Struct. 2014, 23, 105017.

[23] F. Carpi, D. De Rossi, IEEE Trans. Dielectr. Electr. Insul. 2005, 12, 835.

[24] M. Tian, Z. Wei, X. Zan, L. Zhang, J. Zhang, Q. Ma, N. Ning, T. Nishi, Compos. Sci. Technol. 2014, 99 , 37.

[25] D.M. Opris, M. Molberg, C. Walder, Y.S. Ko, B. Fischer, F.A. Nüesch, Adv. Funct. Mater. 2011, 21, 3531 .

[26] S. Zakaria, P.H.F. Morshuis, M.Y. Benslimane, L. Yu, A.L. Skov, Smart Mater. Struct. 2015, $24,55009$.

[27] D. Gatti, H. Haus, M. Matysek, B. Frohnapfel, C. Tropea, H.F. Schlaak, Appl. Phys. Lett. 2014, 104, 052905.

[28] A. Tröls, A. Kogler, R. Baumgartner, R. Kaltseis, C. Keplinger, R. Schwödiauer, I. Graz, S. Bauer, Smart Mater. Struct. 2013, 22, 104012.

[29] J. Huang, S. Shian, R.M. Diebold, Z. Suo, D.R. Clarke, Appl. Phys. Lett. 2012, 101, 122905.

[30] Z. Suo, Acta Mech. Solida Sin. 2010, 23, 549.

[31] X. Zhao, W. Hong, Z. Suo, Phys. Rev. B - Condens. Matter Mater. Phys. 2007, 76, 134113.

[32] F. Carpi, I. Anderson, S. Bauer, G. Frediani, G. Gallone, M. Gei, C. Graaf, C. Jean-Mistral, W. Kaal, G. Kofod, M. Kollosche, R. Kornbluh, B. Lassen, M. Matysek, S. Michel, S. Nowak, B. O’Brien, Q. Pei, R. Pelrine, B. Rechenbach, S. Rosset, H. Shea, Smart Mater. Struct. 2015, 24, 105025.

[33] S. Rosset, L. Maffli, S. Houis, H.R. Shea, Proc. SPIE 2014, 9056, 90560M.

[34] S. Zakaria, L. Yu, G. Kofod, A.L. Skov, Mater. Today Commun. 2015, 4, 204.

[35] F.B. Madsen, L. Yu, A.E. Daugaard, S. Hvilsted, A.L. Skov, RSC Adv. 2015, 5, 10254.

[36] L. Yu, S. Vudayagiri, S. Zakaria, M.Y. Benslimane, A.L. Skov, Proc. SPIE 2014, 9056, 90560S.

[37] M.A. Brook, H.U. Saier, J. Schnabel, K. Town, M. Maloney, Ind. Eng. Chem. Res. 2007, 46, 8796.

[38] X.-M. Zhang, H. Li, W.-X. Chen, L.-F. Feng, Polym. Eng. Sci. 2012, 52, 1740. 